\title{
Student's Attitude Toward Science: as Impact of Using Student Created Case Studies Method
}

\author{
Moh. Najih Wafi ${ }^{1}$, Wuryadi ${ }^{2}$ \\ \{najihwafi2@gmail.com¹, sutomowuryadi@yahoo.co.id² \\ ${ }^{1,2}$ Universitas Negeri Yogyakarta, Jl. Colombo No. 1, Karang Malang, caturtunggal, Kec. Depok, \\ Kabupaten Sleman, Daerah Istimewa Yogyakarta , Indonesia 55281
}

\begin{abstract}
The observation results at X IPA class in SMAN 1 kalasan are student's interest in biology getting low and their attitude toward science in Biology tend to be negative. This study aimed to know the effectivity of student created case method in improving attitude toward science. This study employed a quasi-experimental with a pretest and post-test control group design. The population of the study was X IPA SMA 1 Kalasan students. Independent t-test and $\mathrm{N}$-gain test was used for the data analysis technique. The results of the Independent t-test analysis showed sig. (2-tailed) 0,000 that means $\mathrm{H}_{0}$ was rejected, the $\mathrm{N}$-gain test analysis in the control class had a value of 0.04 while the experimental class had a value of 0.24 . The data analysis showed that the student created case studies method is effective to improve student's attitude toward science in kingdom plantae materia.
\end{abstract}

Keywords: attitude toward science, impact, student created case studies method.

\section{Introduction}

The presence of the 2013 curriculum in learning activities requires teachers to apply the concept of the student center in learning. In this activity, the teacher acts as an accompany or facilitator for students. The concept of student center, in learning activity, places student as the center of the learning process. In its application, students are expected to be active and independent in the learning process, who take responsible and can be initiative in knowing their own study needs, finding the source of information to answer the needs, building and presenting their knowledge based on the source they find. In certain limits, students can choose what they want ti learn. The learning strategy in 21 st Century, requires teachers to apply learning activity which has principles of: learning process which center on students (student centered), improving students' creativity, creating interesting, happy dan meaningful atmosphere, learning through a direct action carried out by students by emphasizing experimentation, and then creating learning in real situations and actual contexts through a contextual approach [1].

In implementing the concept of a student center in the classroom, the teachers have to be able to condition and adjust the classroom atmosphere to make students have a high enthusiasm in participating the learning activity. The problem that might be faced by the teacher is that not all students feel interested or can even feel bored with such learning activities. Learning the science family in schools often creates the impression of being less attractive to students, because the teacher's presentation in the classroom is more focused on achieving curriculum targets so that the classroom atmosphere becomes less enthusiastic. 
Internal factors that are expected to influence this are student attitudes towards objects related to science lessons [2].

Based on the results of observations made by researchers at SMAN 1 Kalasan, in biology learning activities student's interest in biology learning are getting low and their attitude toward science in Biology tend to be negative. As a result, students' interest in biology subjects will decrease, even if they want to easily understand the material in certain subjects then first there must be an attitude of interest in the lesson. The attitude and interest of students towards biology is called the attitude toward science (attitude towards biology) because Biology is included in the family of science.

Attitudes towards science can be either a negative attitude or a positive attitude, in term of students' views on science which in this study is specific to Biology as science education. The attitude towards science (attitude toward science) in the State of Australia is the most important goal of Science education. Because his relates to students' interest in carrying out learning activities, so that indirectly it will impact on student achievement, and further this will give an impact on student interest in choosing their careers related to science in the future [3].

Attitude toward science as expressed by Osborne [4] is an attitude towards scienceBiology learning activity including feelings, beliefs dan values possessed by students about a science object (in learning biology in the subject of kingdom plantae). In Desy et al. [5], the attitudes include: perception of Biology teacher in school. the view about Biology as a subject in school, learning Biology as values in society, enjoying biology learning experiences, interests in biology, and attitudes toward biology at school.

Case-study based learning method was chosen as an alternative to improve attitude toward student science, then from several methods selected student created case studies learning method. This method was chosen as an alternative to resolve the findings of the problem in the field. Sudjana [6] explains that learning by using the case study method has advantages, among others; students gain practical experience, learning activities become interesting, subject matter can be more easily understood by students, students can learn by using a variety of available sources, and students will be trained to actively interact with both their friends and teachers. Raju \& Sanker [7] suggested that the importance of using case studies in the world of education is to expose students to real-world problems that students might face. By applying case studies in learning not only students find learning immersion, but for teachers / lecturers will also find teaching experience [8]. The use of case studies in learning activities can also increase student motivation and interest. Davis \& Wilcock [9] try to explore students' feelings by interviewing several students who get teaching with case studies, they get recognition from one of the students, as follows:

“... well, it's real stuff isn't it? Otherwise you can feel like you're just doing something for the sake of it. When you do a case study you go out and find information that is being used in real life. It's something different where you actually apply what you're learning ... “.

Students who were observed using case-study based learning confessed that they enjoyed learning using the method because from the method they can implement the lesson to solve the reallife problem.

Scientific learning approach combined with student created case studies learning method will eventually make a supporting concept to student center concept in learning. Also, it will make the learning more optimal and both of the approach and the learning method more comprehend. In addition, student-created case studies learning methods require students to be 
able to solve or find solutions, to take lessons from the topic of problems raised in the learning process. When students are involved directly in learning, students will naturally feel interested in the learning and the lesson itself will be very imprinted in their mind or it can be said that the knowledge obtained by the students will be kept in thought. From the various descriptions above, research will be carried out with the aim of knowing the effectiveness of student created case studies learning methods on attitude toward science in class X high school students in learning kingdom plantae materi.

\section{Method}

\subsection{Research design}

This research was an experimental research which qas included in the quasi-experiment design with the design of pre-test and post-test control group design. In the experimental class, the treatment was given using the student created case study learning method while the control class employed was the discussion learning method. The treatment scheme in the experimental class and control class can be seen in the table below:

Table 1. The scheme of treatment in the experimental class and control class.

\begin{tabular}{lccc}
\hline \multicolumn{1}{c}{ Group } & First measurement & Treatment & Last measurement \\
\hline Experiment & $\mathrm{O} 1$ & $\mathrm{X}$ & $\mathrm{O} 2$ \\
Control & $\mathrm{O} 3$ & - & $\mathrm{O} 4$ \\
\hline
\end{tabular}

\section{Description :}

- O1 : measurement of the initial ability of the treatment class

- O2 : measurement of the final ability of the treatment class

- X : : the group treated by using student created case studies method

- O3 : measurement of the initial ability of the control class

- O4 : measurement of the final ability of the control class

\subsection{Population and sample}

The population in this study were students of class X IPA SMAN 1 Kalasan. Then, from the population, samples were taken to be used in the study. The study was conducted during the second semester of the 2018/2019 academic year with the subject of kingdom plantae. The research sample was selected through simple random sampling method, on the basis of consideration of the ability of students to be considered homogeneous at the beginning of the first-class division and students used as research subjects were accustomed to carry out problem-based learning (case studies) and scientific approaches. The sampling activity was determined by students of class X IPA 3 as a control class and students of class X IPA 2 as an experimental class.

\subsection{Instrument}

The research instrument employed in this study wass a non-test instrument attitude toward science questionnaire using an instrument developed by Desy et al., (2011). Before the instrument employed, first it was validated through expert judgment, after the validation was complete then the grammar and writing procedures were revised. As for indicators of attitude toward science consists of 7 principal indicators of attitude. The 7 indicators consist of; 
Perceptions of science-biology teachers in schools, views on school-biology, the value of biology in society, self-concepts in biology, enjoy the experience of studying biology, interest in biology, and attitudes towards schools of biology.

\subsection{Research procedur}

The research steps taken were: (1) Preparation which included making learning devices for the experimental class and the control class, doing the instrument trials. (2) Giving the pretest, to the control class and the experimental class. (3) The implementation of the experimental class learning uses a scientific approach with a created case studies student learning method in which the learning activities begin with the teacher dividing the article to each group as a reference for finding / making a case study, then from the created case it is then used as discussion material in the group. From the results of the discussion of each group, it can be expected that there will be a number of cases that can be appointed as well as used as learning material in the class. While the implementation of the learning control class uses a scientific approach only. (4) Giving post-test to the control class and the experimental class.

\subsection{Data analysis}

The hypothesis test employed was an independent t-test with a significance level of $5 \%$, then an N-gain test was performed to determine the significance of the increase in pre-test and post-test. Before data analysis is carried out, a prerequisite analysis test is carried out in the form of distribution normality test and variance homogeneity test. In the analysis of distribution normality test and variance homogeneity test, the Sig value is obtained. (2-tailed)> 0.005 which means that all data obtained has a normal distribution and originates from a homogeneous variant.

\section{Result and Discussion}

In summary, the description of the data students 's attitude toward science can be seen in the table below:

Table 2. Description of student's attitude toward sciene score.

\begin{tabular}{lcccc}
\hline \multirow{2}{*}{ Description } & \multicolumn{2}{c}{ Experiment class } & \multicolumn{2}{c}{ Control class } \\
& Pree-test & Post-test & Pree-test & Post-test \\
\hline Average & 73,63 & 80,08 & 73,76 & 74,96 \\
Maximum score & 82 & 88 & 85 & 82 \\
Minimum score & 56 & 70 & 67 & 70 \\
\hline
\end{tabular}

On Table 2, the experimental group has an average pretest score of 73.63 , and the posttest is 80.08 . In the control group the average pretest score was 73.76, and the posttest was 74.96. If the average score of the pretest is obtained, the initial state of the control class and the experimental class is concluded as homogeneous. To support and prove that the initial homogeneous state of the control class and experimental class will be carried out independent t-test. The results of the independent t-test from the pre-test control class and the experimental class obtained the Sig. (2-tailed) 0.924. Because the value of $\mathrm{p}>0.05$, it can be concluded that there is no significant difference in the initial state of the control class and the experimental class. 
The results of the final measurement (post-test) showed that the experimental group had an average score of 80.08 , while the control group had an average score of 74.96. Seen from the difference in the average score, it can be concluded that the treatment given to the experimental class was successful. However, to prove whether the learning with a scientific approach combined with student created cases study methods on attitude toward science significantly effective, statistical tests will be conducted using the independent t-test which will be described in full on the hypothesis test points.

Based on the hypothesis test, it is known that the scientific approach to the student created learning method case studies is effective on the attitude toward the science of students. This can be seen on the different tests that are conducted (independent t-test) on attitude toward science control class students with experimental class getting a significance value of 0,000 which means $\mathrm{H} 0$ is rejected in which it means that there are significant differences. Thus, it can be concluded that attitude toward science students, in the experimental class and control class after getting treatment, differed significantly. The average score of the measurement results of attitude toward student science can be seen in the diagram below:

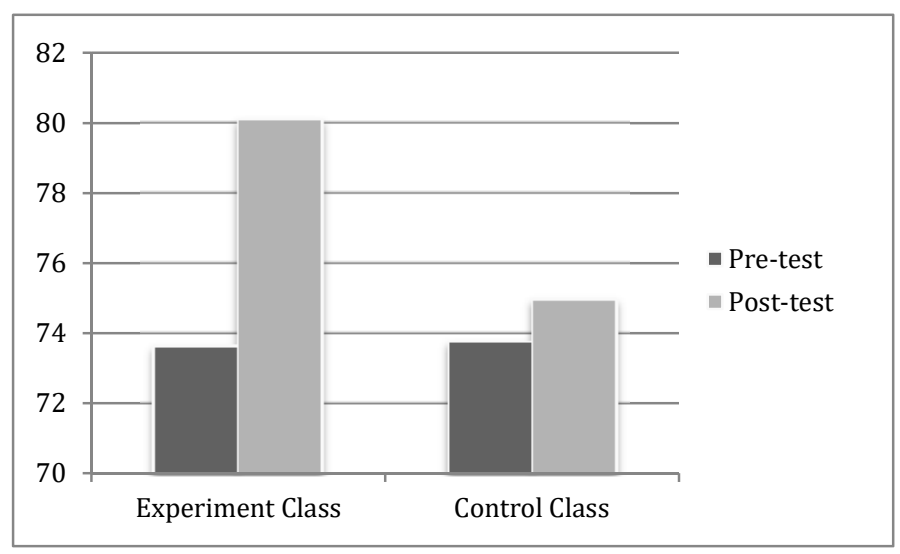

Fig. 1. The result diagram measurement of student's attitude toward science.

On Figure1, it shows that in the experimental class the average value of the pre-test was 73.63 and the average score of the test post was 80.08 . In the control class the average pre-test value was 73.76 and the average test post value was 74.96. The results of the measurement of attitude toward the science of control class students and experimental classes, each increased after learning activities. However, the increase in the average score of attitude toward science occurred more significantly in the experimental class than the results of the average control class. When the initial measurement in the experimental class obtained an average score of 73.63, the score obtained in the experimental class increased after getting learning activities, with the acquisition of an average score of 80.08 . Whereas in the control class there was an increase, but it was not so significant and far below the average score in the experimental class. When the researcher conducting initial measurements, the control class obtained an average score of attitude toward science score of 73.76. The score for attitude toward science after learning activities in the control class also increased but not significantly with the acquisition of an average score of 74.96 . 
To prove how much the increase in the acquisition of pretest and posttest scores, data analysis was performed using the $\mathrm{N}$-gain score test. $\mathrm{N}$-gain test results in the experimental class and control class can be seen in the diagram below:

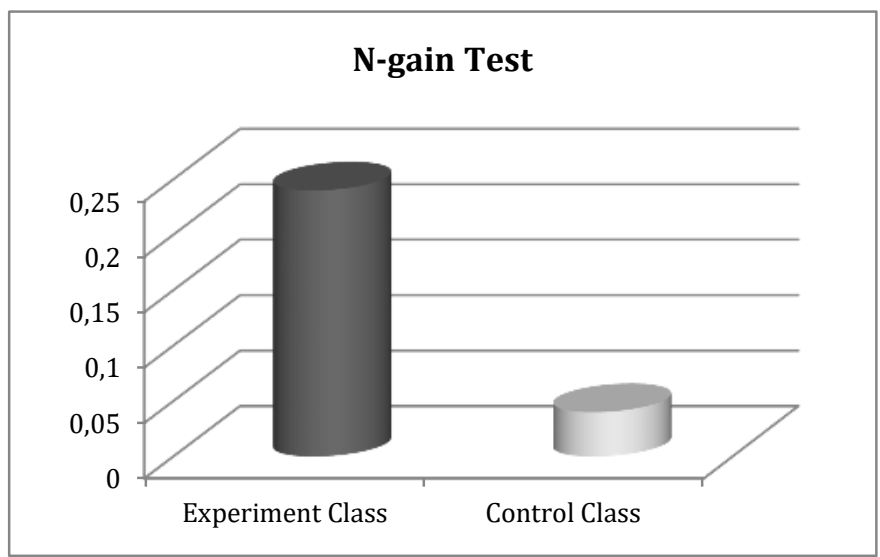

Fig. 2. The results of the n-gain test scores on attitude toward the science of the control class students and the experimental class.

On Figure 2, it can be seen that there is a difference in the gain value between the experimental class and the control class. In the experimental class, an increase is shown in value of 0.24 in which it can be concluded as "low" category, while in the control class an increase is shown in value of 0.04 with "low" category. Even though the results of the N-gain test between the control class and the experimental class are concluded as low criteria, if the details is also being measured, the results in the experimental class are better than the control class. Details of the significance of value improvement are as follows: with scores of $66.67 \%$ of students increase with the category "low", 33.33\% of students belong to the category of "moderate" and $0 \%$ of students who experience an increase in the high category. While in the control class, $100 \%$ of students experienced an increase in the "low" category.

The lowness of improvement score of students in control class happened because there is the time when teachers teach students but some of the students the class were not really enthusiast and indirectly it infected the rest of the students of the class. For example, when a presentation's discussion is up, there are only a few students who respond to the group presenting and some of them have to get stimulated by the teacher to ask. In addition, from the data obtained, in filling the post-test on attitude toward science and also post-test, most students chose the same option with the option they chose in the pre-test questionnaire. Thus, this case causes the acquisition of attitude scores toward science students in the control class is lower when compared to students in the experimental class.

Learning activities which apply scientific approaches involve students to be active and directly involved in learning activities. In addition, the student created case studies learning method is also a kind of learning method that makes students be the main actors in learning. As in the learning which is carried out students will make students look for a case / topic of learning that then will be discussed and resolved in their group discussions.

Based on researcher's observation, in learning activities that apply a scientific approach which carry out student created case studies learning methods, students have a sense of 
interest and feel happy to learn the materials in biology, and these traits are part of aspects in attitude toward science.

Some opinions state that students who are directly involved in learning activities, such as practicum in the laboratory, feel happy and interested in the lesson. The excitement surrounding activities in the laboratory encourages them to feel interest in pursuing further education and will even encourage students to be interested in careers in science. Direct experience in science can increase their interest in scientific disciplines [10]. One way in learning activities that can involve students to have direct experience is by inviting students to learn on the basis of problems. Because with problem-based learning, students will feel to be as if they are directly involved in the case. Gomez-arizaga [11] students enjoy with the learning activities where they are being involved directly because they have the opportunity to create, share, and realize their ideas.

In biology learning activities, it is very important for teachers to always make students have self-motivation in learning biology. Learning motivation can direct students to conduct scientific literacy studies to understand various knowledge, identify scientific questions, draw conclusions based on evidence, and make decisions [12]. Research conducted by Akbar [13] shows that motivation has a significant relationship to attitudes, until finally motivation will influence the stages of decision making. Attitude toward science is the attitude of students towards biology that can be either a negative attitude or a positive attitude. In this attitude there are various aspects, including interest in pursuing a career in the field of science. Students who have a high attitude toward science mean that they have good self motivation in learning biology.

Motivation in learning science can lead students to continue to higher education in reaching future scientific careers [14]. If students have high motivation in learning biology, so they will be interested in learning biology. Motivation will also affect students' decision choosing science related careers in the future. In addition, the higher the motivation to learn, the higher the learning outcomes obtained by students [15].

Based on the research done and supported by several relevant theories, it can be concluded that the scientific approach with student created case studies learning methods proved to be effective to improve students' attitudes toward science in the kingdom plantae material.

Attitude toward science will facilitate students in developing science concepts, which in turn improves scientific academic achievement. In addition, learning science should be more contextual in which it means that science activities should be directed to observe the scientific symptoms that exist around students [16].

\section{Conclusion}

The use of a scientific approach along with the student created case studies method is effective to improving on the attitude toward science class of $\mathrm{X}$ high school students in the kingdom plantae subject material. This can happen because the case study learning method makes students directly involved in learning activities. Those activities are such as practicum in the laboratory, or practicum / field observation. Thus, it will make students feel happy and interested in the lesson. The excitement of the surrounding activities in learning can encourage their interest in pursuing further education and will even encourage students to be interested in careers of science field. 


\section{References}

[1] Hosnan, M., \& Sikumbang, R.: Pendekatan Saintifik dan Kontekstual dalam Pembelajaran Abad 21: Kunci sukses implementasi kurikulum 2013. Ghalia Indonesia, Bogor (2014)

[2] Iksan, Z. HJ., Halim, L., \& Osman, K.: Sikap Terhadap Sains dalam Kalangan Pelajar Sains Peringkat Menengah dan Matrikulasi. Jurnal Pendidikan ISSN: 0128-7702. Universitas Kebangsaan Malaysia, Selangor (2006)

[3] Fraser, B. J.: TOSRA Test of Science-Related Attitudes Handbook. The Australian Council for Educational Research Limited, Victoria (1981)

[4] Osborne, J., Simon, S., \& Collins, S.: Attitudes towards science: A review of the literature and its implications. International Journal of Science Education. Vol. 25, pp. 1049-1079 (2003). Doi: 10.1080/0950069032000032199

[5] Desy, E. A., Peterson, S. A., \& Brockman, V.: Gender Differences in Science-Related Attitude and Interest Among Middle School and High School Student. FALL. Vol. 20(2), pp. 23-30 (2011)

[6] Sudjana, N.: Membuat siswa aktif belajar (65 cara belajar mengajar dalam kelompok). Sinar Baru Algesindo, Bandung (1996)

[7] Raju, P.K., \& Sanker, C.S.: Teaching Real-World Issues through Case Studies. Journal of Engineering Education. Vol. 88 (4), pp501-508 (1999), https://onlinelibrary.wiley.com/doi/pdf/10.1002/j.2168-9830.1999

[8] Mustoe, L.R., \& Croft, A.C.: Motivating Engineering Students by Using Modern Case Studies. European Journal of Engineering Education. Vol. 15 No 6, pp. 469-476 (1999), https://www.ijee.ie/articles/Vol15-6/ijee1101.pdf

[9] Davis, C., \& Wilcock, E.: Teaching Materials Using Case Studies. UK Centre for Materials Education. (2003), http://www.materials.ac.uk/guides/casestudies.asp..

[10] Guenette, A., Francis, A.M., \& Morley, T.: Career experiences and choice processes for secondary science students. Proceedings of Connections 2007 Faculty of Education University of Victoria (pp. 77-84). Routdlege, London (2007)

[11] Gomez-arizaga, M.P., Bahar, A.K., Maker, C.J., Zimmerman, R., \& Pease, R.: How Does Science Learning Occur in the Classroom? Students' Perceptions of Science Instruction During the Implementation of the REAPS Model. Eurasia Journal of Mathematics, Science \& Technology Education. Vol. 12(3), pp. 431-455 (2016). Doi: 10.12973/eurasia.2016.1209a.

[12] Bryan, R.R., Glynn, S.M. \& Kittleson, J.M.: Advanced placement intent of high school students learning science. pp. 1049-1065 (2011). doi: 10.1002/sce.20462

[13] Akbar, Y.J.: Analisis pengaruh motivasi konsumen, persepsi kualitas, dan sikap konsumen terhadap keputusan pembelian sepeda motor honda. S1 thesis, Universitas Diponegoro Semarang (2010), http://eprints.undip.ac.id/19406/.

[14] Bryan, R.R., Glynn, S.M. \& Kittleson, J.M.: Advanced placement intent of high school students learning science. pp. 1049-1065 (2011). doi: 10.1002/sce.20462

[15] Stevani: Analisis Pengaruh Motivasi Belajar terhadap Hasil Belajar Ekonomi Siswa Kelas X SMA Negeri 5 Padang. Journal of Economic and Economic Education. Vol. 4(2), pp 308-314 (2016), http://dx.doi.org/10.22202/economica.2016.v4.i2.669

[16] Rahmad, M., Kurnia, N. \& Hadi, M.S.: Science process skills and attitudes toward science of lower secondary students of merbau island: A preliminary study on the development of maritime based contextual science learning media. Journal Of Educational Science. Vol. 2(2), pp. 90-99 (2018) 
